\title{
CFRP の特性と自動車部材への適用事例について
}

\section{1.はじめに}

炭素繊維は 1970 年代に誕生した比較的新しい素材であ る. 近年, 軽量・高剛性・高強度を実現できる材料として 炭素繊維強化プラスチックの用途範囲が拡大してきた。炭 素繊維は，エジソンが世界で初めて灯した電球に使われた 日本の竹を炭にしたフィラメント (繊維) のイメージで伝 えられるが，その名のとおり炭素でできた繊維基材（炭で はなく，繊維）である.

一方, 繊維強化プラスチック（FRP, Fiber Reinforced Plastics）は, 繊維を樹脂で固めた材料であり, FRP のイ メージを伝える喻えとしては，土壁がよく用いられる。土 壁は竹で編んだ芯に土を練り固めた構造で, 土だけでは脆 くて崩れてしまうが，竹が中に入っているので形態を維持 し，竹だけでは建物を支えられないが，土があるので壁と いう構造材となる。では, 炭素繊維強化プラスチック (CFRP, Carbon Fiber Reinforced Plastics) はというと, 説明のためのなかなか良い比喻がない（土壁の中の竹を炭 にしても適当でない).

そこで本稿では，はじめにCFRP の特徴を炭素繊維, 設計上の特徴, 成形技術から説明し, CFRP 適用の最大の メリットである軽量化を中心に, 自動車部材への適用事例 を紹介する。

\section{2 ．炭素繊維の特徵}

\section{1 炭素繊維の変遷}

図 1 に炭素繊維の変遷をまとめた。1970 年代に開発さ れた炭素緎維は，国内では，まずスポーツ用途に適用され， 従来の金属材料では成し得ない軽量と優れたフィーリング を実現することで拡大してきた。この分野では標準材料と 言っても良い地位を確立している. また軽量化が最重要課 題の航空宇宙分野では, 新しい材料であったので慎重に適 用検討が開始された. 90 年代に入り, スポーツ用途の急 激な拡大に合わせて, 素材自身の開発と CFRP の設計お よび成形技術が進歩し, 90 年代の後半から一般産業用途 へ拡大した. 最近では航空機用途への実用化が急加速する とともに, 一般産業用途においても自動車用部品への関心

\footnotetext{
* Kimoto, Yukitane

東レ(株) コンポジット開発センター

愛媛県伊予郡松前町大字筒井 1515（テ791-3193）

2008. 4.14 受理
}

木 本 幸 扸*

が高まり，軽量化に対する期待が大きくなってきた.

用途拡大にしたがい炭素繊維の価格も低下しているが, 長年の歴史と膨大な生産量を誇る金属材料にはまだまだ及 ばない. 当面, 機能優先で採否判断されるケースが多いと 思われるが，今後，技術開発と共に需要が広がれば，価格 面でも受け入れられやすくなる可能性を秘めている.

炭素繊維を供給しているメーカーは，東レ，東邦テナッ クス (帝人グループ), 三菱レイヨンの日本企業 3 社で, 世界の約 7 割程度のシェアを占める (図 2) ${ }^{1)}$. 炭素繊維は メイドインジャパンを誇れる素材であり, 主要 3 社が合成 繊維を要素技術に持つ会社であることは興味深い.

\section{2 炭素繊維の特徴}

炭素纎維は，合成繊維の一種であるアクリル緘維 (PAN, ポリアクリロニトリル）を出発原料としている．これを高 温下で焼成（炭化あるいは黒鉛化）することで炭素繊維が 得られる。炭素繊維自体は比重が鋼材の約 $1 / 4$, 強度およ び弾性率は約 10 倍であるが, 炭素繊維単体では構造用材 料として使用できないので, 必ず CFRP という形態で使 用する。

ある材料を使った際の構造の軽量化の指数として, 比弾 性率，比強度がよく使われる．比弾性率とは材料の弾性率 をその密度で除した值, 比強度は強度を密度で除した值で あり, 数值が大きい程, その材料で設計された構造体が軽 量化できることを示す. CFRP の繊維方向の特性は, 鋼材 に比較し, 比弾性率, 比強度ともおおよそ 5〜10 倍の值で ある。これは構造を鋼製から CFRP 製に置き換えれば, $1 / 5$ 〜 1/10の重量の構造が可能になるということである. し かし多くの場合, 䋊維の積層構成による最適設計が必要に なるので，現実的な軽量化は $1 / 2 \sim 1 / 5$ である.

その他，炭素繊維には，錆びない，X 線透過率が高い， 電磁波遮蔽性がある, 線膨張係数が小さいなどの機能的な 特徵があり, 比弾性率や比強度と組み合わせることでより 高性能の構造を実現することができる.

\section{CFRP の特徵}

\subsection{CFRP の構造}

CFRP は, 直径が約 $6 \mu \mathrm{m}$ の炭素繊維（単系）を多数本 引き揃えた状態に，マトリックス樹脂（たとえばエポキシ 樹脂）が含浸した構造になっている。ここに外荷重が作用 すると，炭素繊維それぞれが外荷重を支える．ある箇所で 繊維が破断すると，破断した周りのマトリックス樹脂が剪 


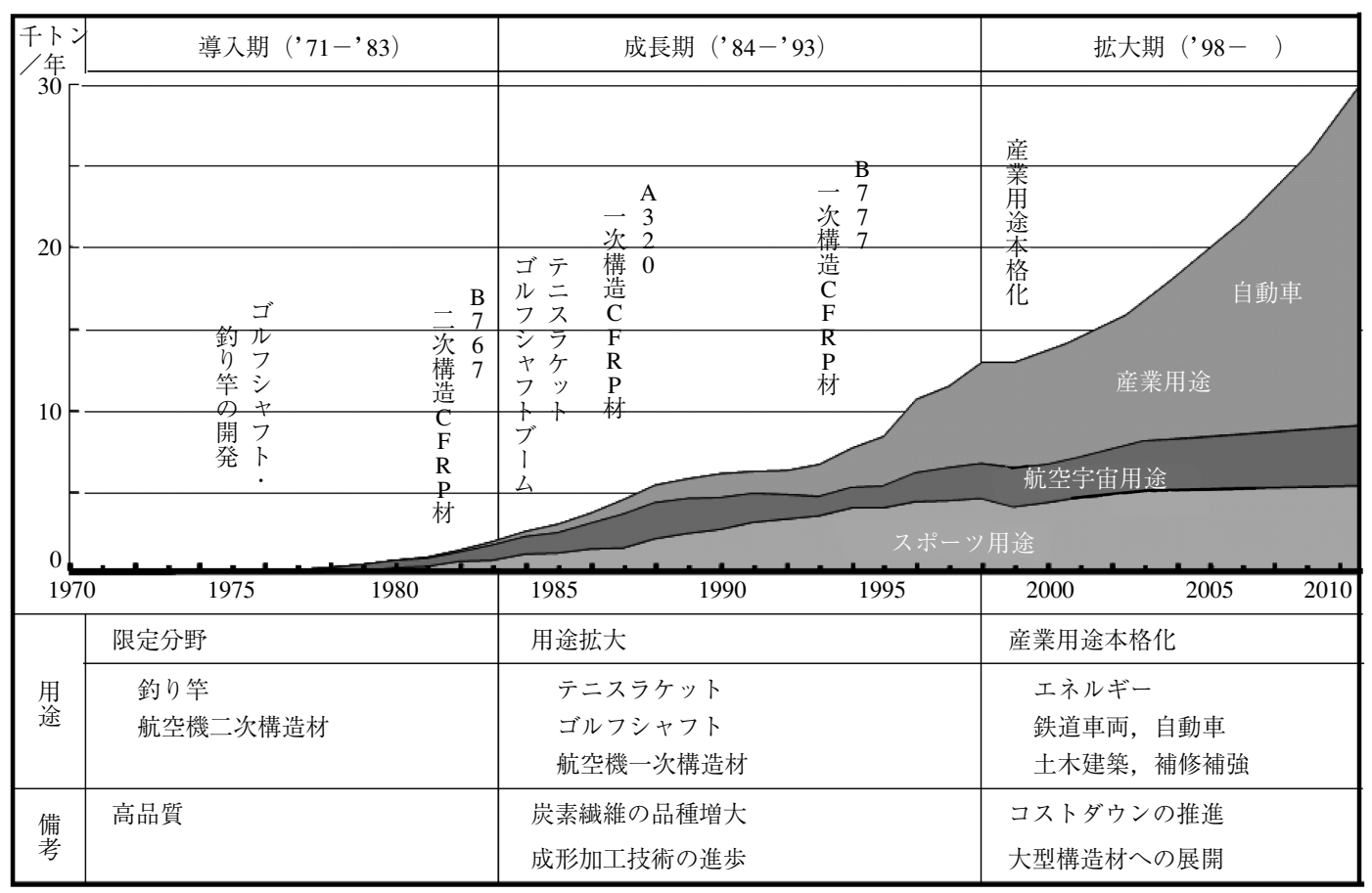

図 1 炭素繊維の変遷

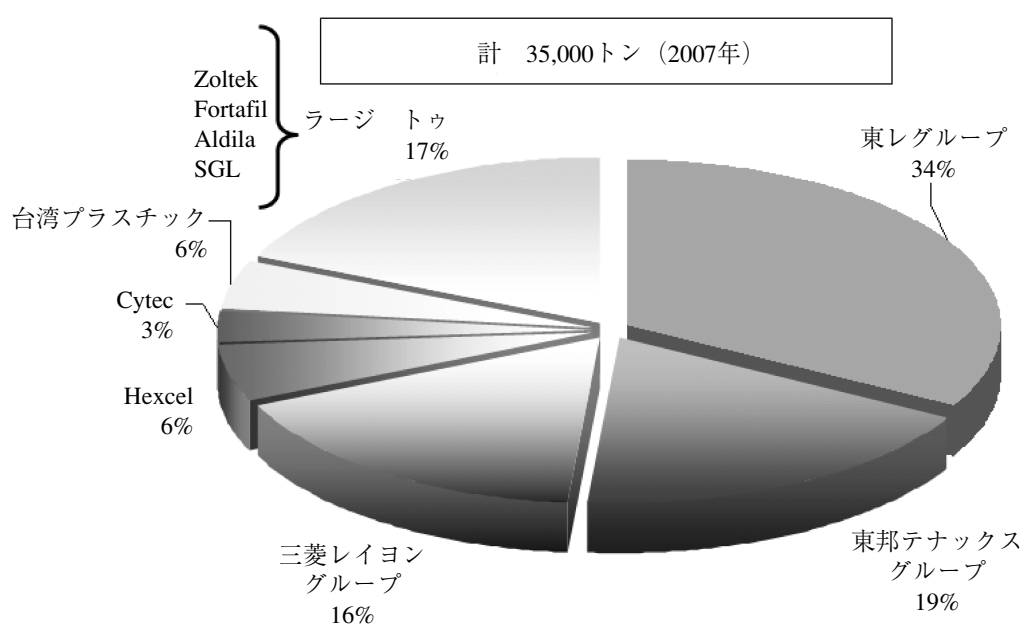

図 2 世界の炭素繊維市場シェア

断によって周辺の健全な炭素繊維に荷重を再配分する。こ の仕組みにより，破断した箇所から離れれば，破断した炭 素纎維も健全な纎維と同様に荷重を支えることができるの で, CFRP 構造は一気に破壊することはない。もしマトリッ クス樹脂が存在しないと破断した繊維は 2 度と荷重を支え られないので, 破断は一気に進展する.

FRP が世の中に出現した当初は瀻維の含有量も低く, また射出成形に用いられる短繊維強化夕イプのように，極 めて短い瀻維が含まれるケースがよく目にされることも あって,「瀻維強化プラスチック」は, その言葉の通り, 瀻維によって強化された樹脂を意味した。 しかし，ここで 紹介する炭素瀻維を使った連続繊維強化タイプの CFRP は, 繊維の含有量も高く, むしろ, 瀻維を樹脂で固めるこ とで炭素繊維の高い特性を発現させている，と捉える方が 正しい.

\subsection{CFRP の特徴}

CFRP の特性の主体は炭素纎維にあるが，さらにCFRP には重要な特徴がある. 図 3 (a) は, 炭素繊維を一方向に 引き揃えて樹脂で固めた，いわゆる一方向板を示している. この板の, 繊維方向を $0^{\circ}$ とてて, 繊維と直角方向までの 角度とその方向の特性を示したのが図 $3(\mathrm{~b})$ である。この 図から明らかなように, 繊維方向の特性は極めて高いが, その特性は繊維と角度を持つほど急激に低下する。このよ うな特性を持つ材料を異方性材料と言い，自動車で主に使 われている鋼材などの等方性材料にはない重要な特性であ る. CFRP の設計者はこの異方性を理解し, 荷重条件に合 わせて纎維の向きを設定しなければならない. 外荷重に応 じた複数の纎維配向角を組み合わせる積層設計(材料設計) を行い，外荷重と支持条件に適した場所に合理的な材料特 性を配置（構造設計）するのである，見方を変えると，構 造の要求特性（荷重条件や境界条件など）が明確であれば 


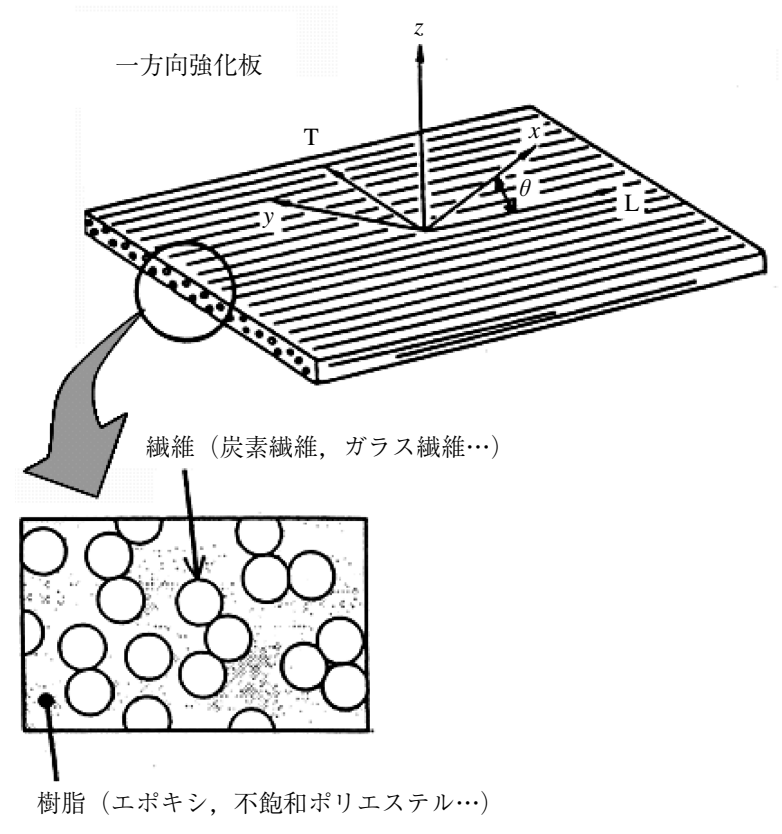

(a) 一方向板

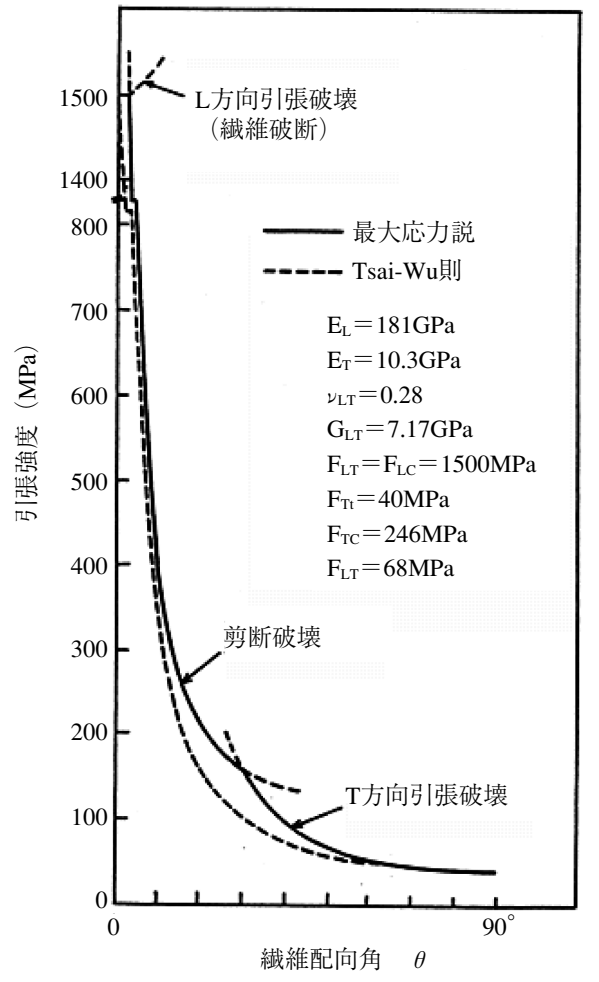

（b）異方性材料特性

図 3 一方向板の特性

あるほど，最適な構造を得ることができる。この自由設計 性がCFRP の大きな特徴である.

身近な例で CFRP の積層設計を紹介する. 図 4 はフィッ シングロッドである．竿は手元が太く, 先に行くほど細く なっている (外形形状が決められている).ささらに笔には, 先調子, 胴調子, 本調子といった曲がり方のバリエーショ ンが必要である. 曲がり方は, 竿の断面剛性（EI）で決 まるから, 外形形状（断面 2 次モーメントI）はそのまま で, CFRP の積層構成を変化させることで, 弾性率 (E) を場所ごとに変化させ，竿全体の調子（EI）を設計する ことができる. CFRP にすることで，一気に設計の自由度 が上がり，多彩な調子を持つ笔が得られるようになったの で, その軽量効果も加わって, 現在ではほとんどの笔がカー ボン製に置き換わってしまった。

\subsection{CFRP の成形法}

炭素繊維の代表的な商品形態は, 繊維, 織物の他, プリ プレグ(炭素緘維に樹脂を含浸させた成形用基材)，チョッ プド糸（射出成形用の強化基材）がある. 瀻維状のものは フイラメントワインディング成形法により円筒形状物を成 形し, プロペラシャフトや圧力容器に, また織物は RTM (Resin Transfer Molding) 成形法により自動車部品など が成形されている，プリプレグはスポーッ用や航空機用部 品の成形用基材して多用され, シートワインドやオートク レーブなどの成形法により部品化される. チョップド糸は 熱可塑性樹脂と混練し, 射出成形によりパソコン筐体など の部品となっている2).

表 1 にCFRP の成形法を, 纎維強化の形態で並べ直し た. 熱可塑性樹脂のペレットによる射出成形は不連続瀻維 による強化形態であり，プリプレグを使用したオートク
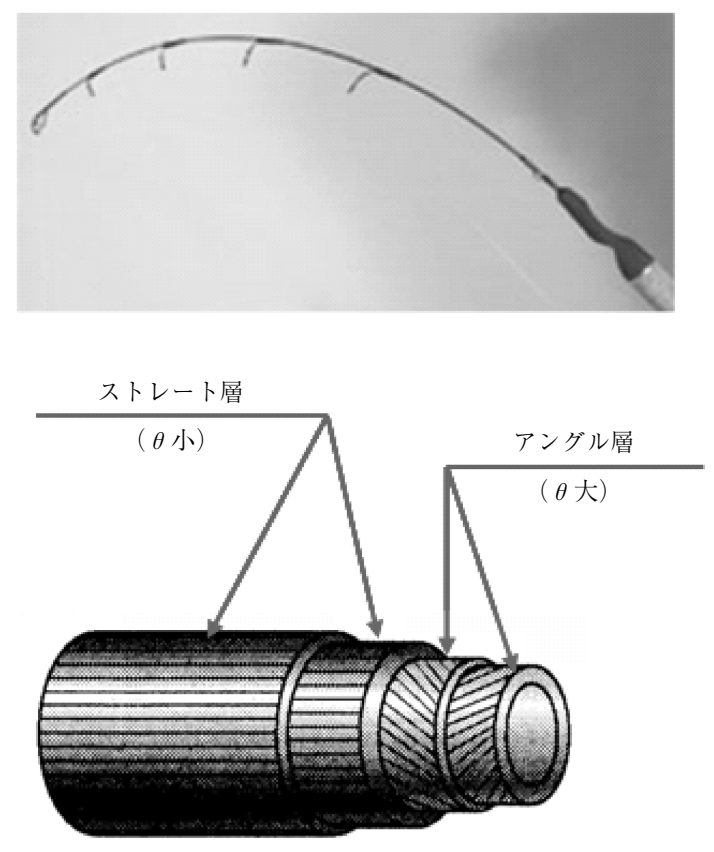

複数の角度構成

図 4 フィッシングロッド

レーブ成形は連続繊維による強化形態である，不連続瀻維 強化の射出成形は成形品の特性は低いが, 量産性に優れ, 連続䋊維強化のプリプレグ成形は極めて高性能な成形品が 得られるが, 量産性にそしい. CFRP の材料, 構造設計と 同様に，実現したい構造に適した成形法を，コストなども 十分に考慮して選択することが重要である.

これらを成形時間と成形品の特性で成形法を関連づける 
表 1 CFRP 成形法

\begin{tabular}{|c|c|c|c|c|c|c|c|c|}
\hline \multicolumn{2}{|c|}{ 成形方法 } & \multicolumn{3}{|l|}{ 使用材料 } & 対象部材 & 特徵 & 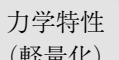 & 量産性 \\
\hline 射出 & & $\begin{array}{l}\text { コンパウンドペレット } \\
\text { 長㵶維ペレット } \\
\text { BMC }\end{array}$ & & \multirow{4}{*}{$\begin{array}{l}\text { 不 } \\
\text { 連 } \\
\text { 続 } \\
\text { 繊 } \\
\text { 維 }\end{array}$} & $\begin{array}{l}\text { 内装・外装 } \\
\text { など }\end{array}$ & $\begin{array}{l}\text { 複雑形状 } \\
\text { 大量生産 } \\
\text { 小型部品 }\end{array}$ & $\times$ & (2) \\
\hline プレス & & $\begin{array}{l}\text { 各種シート材 } \\
\text { SMC, BMC, GMT } \\
\text { プリプレグ }\end{array}$ & & & $\begin{array}{l}\text { 内装 ·外装 } \\
\text { 構造部材 }\end{array}$ & $\begin{array}{l}\text { 平坦形状 } \\
\text { 大量生産 } \\
\text { 大型部品 }\end{array}$ & $x-\triangle$ & (a) \\
\hline $\begin{array}{l}\text { Splay-UP } \\
\text { /RTM }\end{array}$ & & $\begin{array}{l}\text { 繊維 } \\
\text { (カットして } \\
\text { スプレー) }\end{array}$ & & & $\begin{array}{l}\text { 内装 · 外装 } \\
\text { 構造部材 }\end{array}$ & $\begin{array}{l}\text { 複雑形状 } \\
\text { 中-大量生産 } \\
\text { 中一大型部品 }\end{array}$ & $x-\triangle$ & $\bigcirc$ \\
\hline $\begin{array}{l}\text { RTM } \\
\text { Resin Transfer } \\
\text { Molding }\end{array}$ & $\underset{\text { 樹脂 }}{\square}$ & $\begin{array}{l}\text { プリフォーム } \\
\text { (織物, 他) }\end{array}$ & & & $\begin{array}{l}\text { 外装 } \\
\text { 構造部材 }\end{array}$ & $\begin{array}{l}\text { 複雑形状 } \\
\text { 中量生産 } \\
\text { 高い力学特性 }\end{array}$ & $0-(0)$ & $\triangle$ \\
\hline $\begin{array}{l}\text { FW } \\
\text { Filament } \\
\text { Winding }\end{array}$ & & 連続繊維 & & & $\begin{array}{l}\text { プロペラ. } \\
\text { シャフト } \\
\text { タンク }\end{array}$ & $\begin{array}{l}\text { 筒状形状 } \\
\text { 中一大量生産 } \\
\text { 高い力学特性 }\end{array}$ & O- (-) & $\Delta-\bigcirc$ \\
\hline オーブン & & $\begin{array}{l}\text { セミプレグ } \\
\text { プリプレグ }\end{array}$ & $\begin{array}{l}\text { 連 } \\
\text { 続 } \\
\text { 㵶 } \\
\text { 維 }\end{array}$ & & $\begin{array}{l}\text { 外装 } \\
\text { 構造部材 }\end{array}$ & $\begin{array}{l}\text { 平坦形状 } \\
\text { 少量生産 } \\
\text { 高い力学特性 }\end{array}$ & O-@ & $\times-\triangle$ \\
\hline $\begin{array}{l}\text { オート } \\
\text { クレーブ }\end{array}$ & & プリプレグ & & & $\begin{array}{l}\text { 外装 } \\
\text { 構造部材 }\end{array}$ & $\begin{array}{l}\text { 平坦形状 } \\
\text { 少量生産 } \\
\text { 高い力学特性 }\end{array}$ & () & $\times$ \\
\hline
\end{tabular}

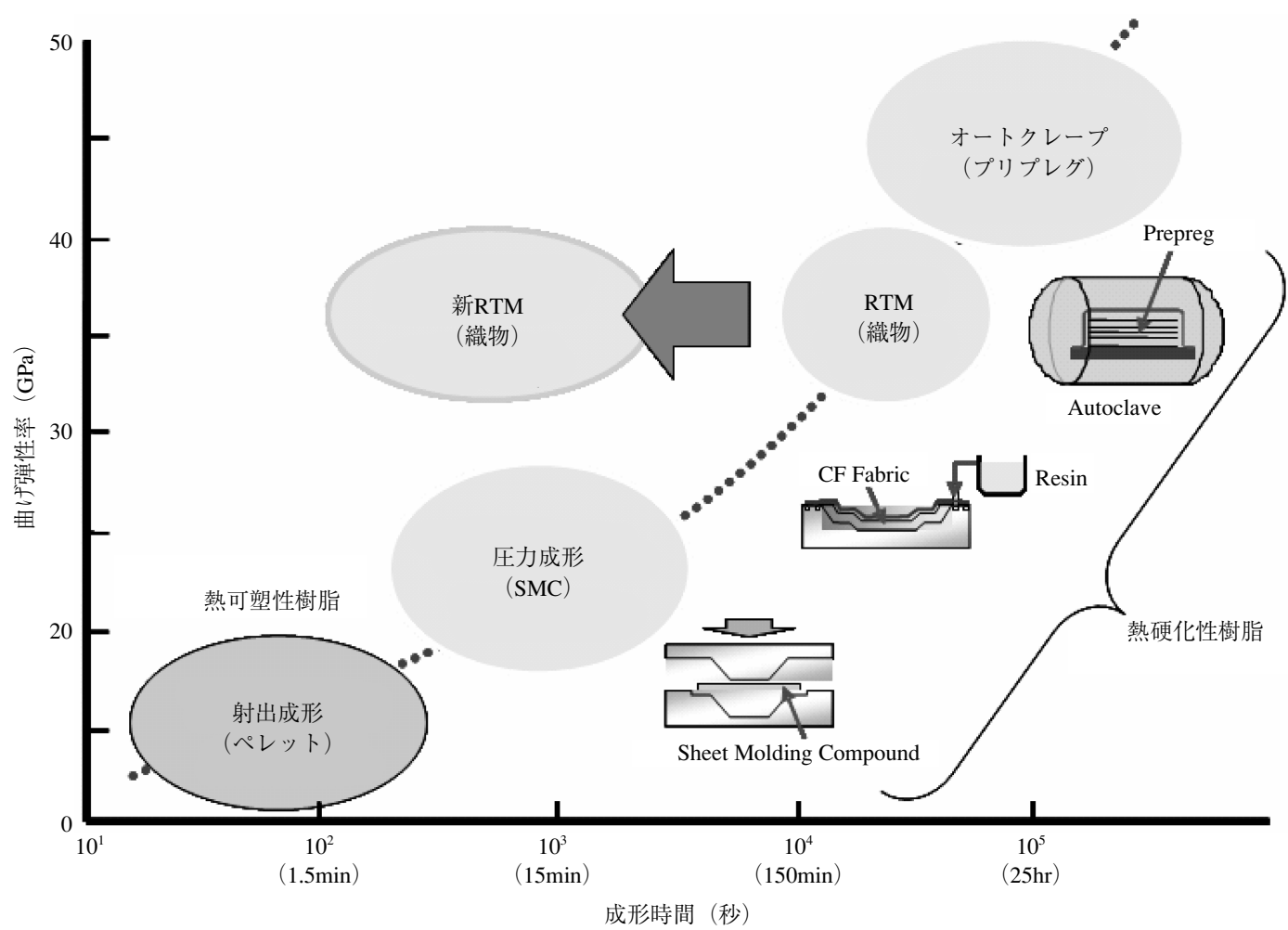

図 5 CFRP の成形法 


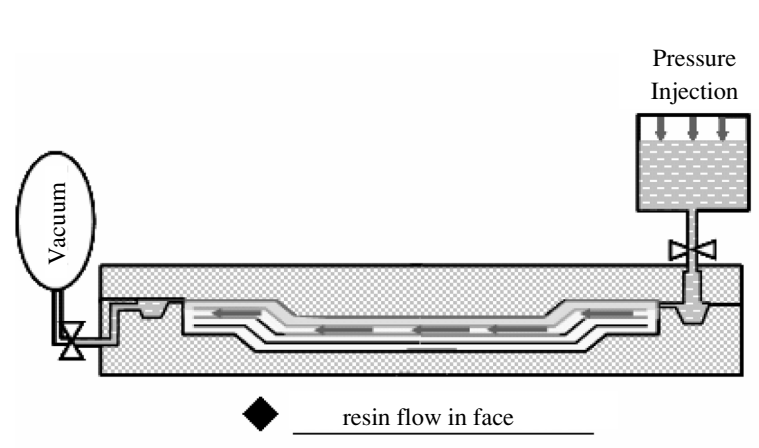

(a) 従来システム

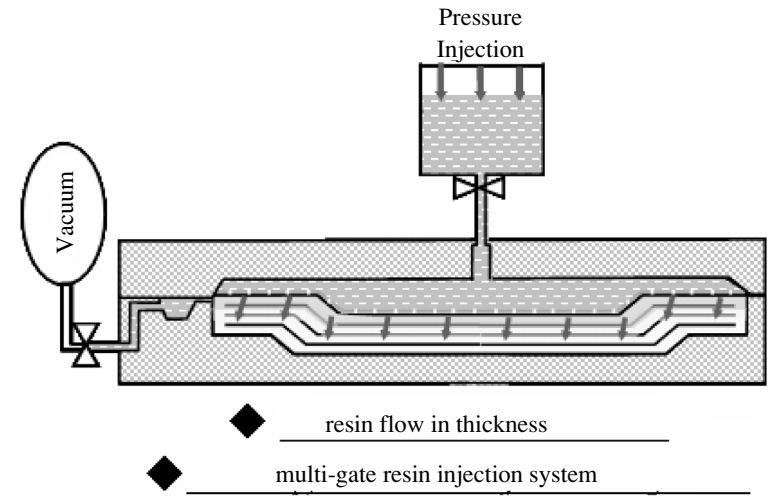

(b) 新システム

図 6 新 RTM 成形システム

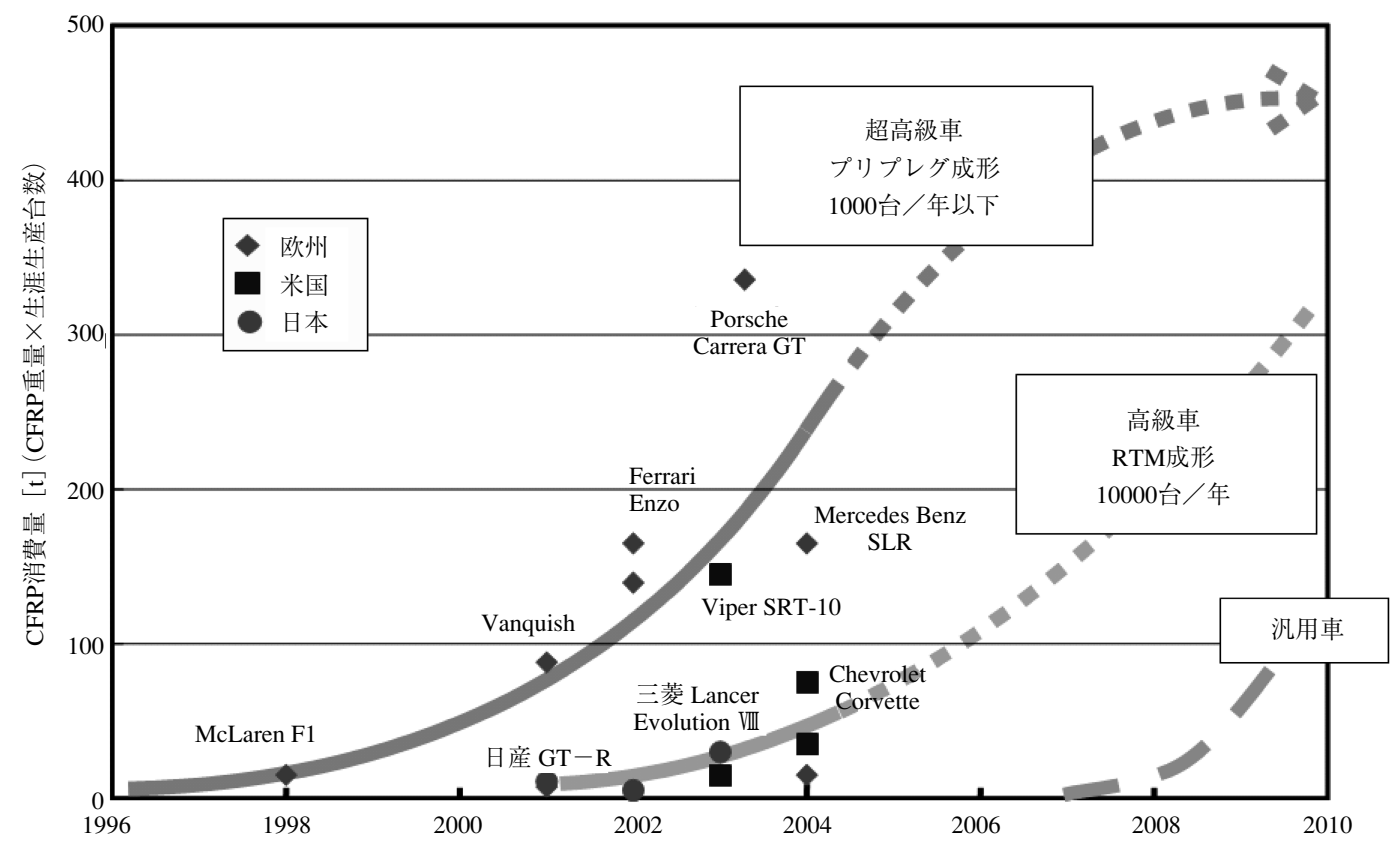

図 7 CFRP 採用車種

と図 5 になる。より軽量化するためには，高い性能である ことが望ましいが，一方で成形時間が長い，すなわち成形 加工コストが高いままでは，より多くの部品には採用され ない.

この中で成形品の特性は十分高いが，従来の成形技術で は成形時間が長かった RTM 成形法に着目し，この成形時 間の短縮を狙った成形技術が最近開発された ${ }^{3)}$.

従来の RTM 成形法 (図 6 (a) ) は, 2 面型で構成される キャビティに炭素繊維の織物をセットし樹脂を注入する. 樹脂は成形品の端部から注入されるので, 流動抵抗の大き な繊維基材の中を進まなくてはならず, 非常に長い含浸時 間を要すると共に, 樹脂の硬化挙動によって成形品の大き さに制限があった，開発された新しいRTM 成形システム (図 6(b)) では，2つの機能を取り込んでいる. 第 1 は, 樹脂を一旦成形品の片側に短時間で展開させ, 成形品の厚 さ方向にのみ含浸させる機能である. したがって極めて短 い含浸距離のため極短時間で含浸が完了する．第 2 に，片 面に展開した樹脂と成形品の間に, 所定の間隔で小さな樹 脂注入孔を設けたセパレータを置き，樹脂を多点同時注入
する機能である.これにより，先の含浸距離が短いことと 相まって，成形品の大きさの制限が大幅に緩和される．従 来は約 160 分を要していた成形品が，この新しいシステム を使うことで約 10 分に短縮されたことが実証されており， これまで $\mathrm{SMC}$ などの非連続繊維強化型の基材でなければ 成し得なかった短時間で, 比較的大型の連続繊維強化 $\mathrm{CFRP}$ 構造体を成形できるようになった。 今後, 自動車構 造体への普及が期待されている.

\section{4. 自動車部材への適用事例}

図 7 にCFRP が自動車部品に採用された事例を車種別 に，年次と使用規模を追ってまとめた。車両市場価格が 1 千万円を超える超高級車から採用され, その使用量は年々 増加しており, 当面, このカテゴリの車種が中心となると 思われる.これらの生産台数はおおよそ 1 千台/年以下で あり, 炭素繊維の使用量としては飽和に近づく. 一方, 年 間生産台数が 1 万台クラスの高級車への採用が始まってお り, 今後の大きな増加が期待される. また，一般汎用車へ の新規採用が 2010 年に向けて登場することが望まれる. 

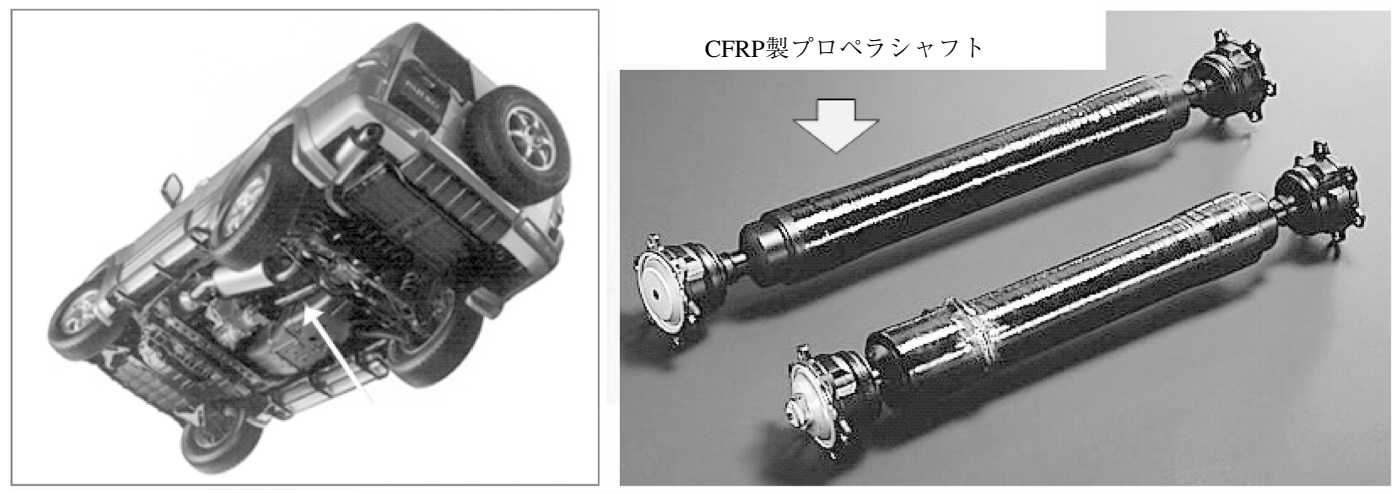

図 8 プロペラシャフト

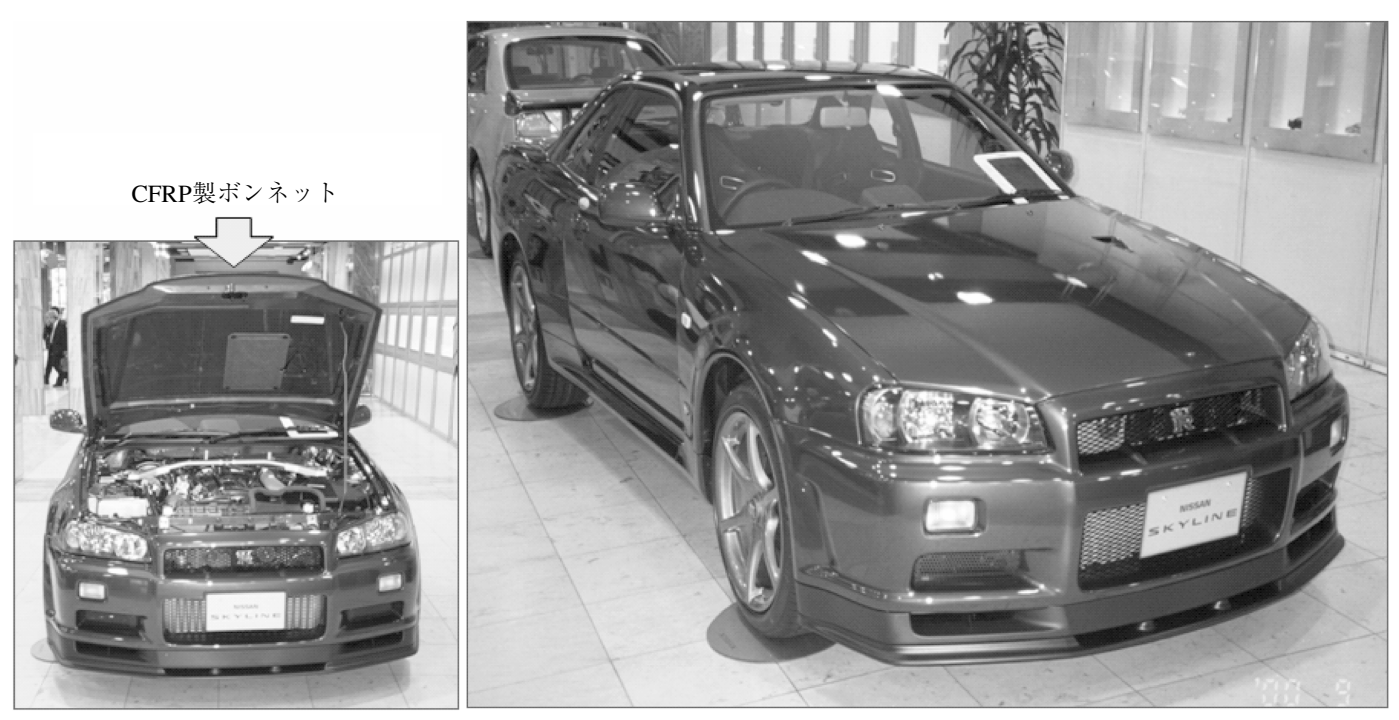

図 9 ボンネット

\section{1 プロペラシャフト}

プロペラシャフトの鋼管部分に CFRPチューブを採用 した事例である。CFRP チューブの国内乗用車への採用は 1993 年のトヨタ “マーク II ” (一部車型) が最初であり, 本格的な量産車への採用は，1999 年の三菱自動車の“パ ジェロ”(全車) である（図 8)。

CFRP 製プロペラシャフトの特徵のひとつは，鋼製では 通常設けられている中間軸受を省略することができること である。これはCFRPチューブの軽量・高剛性により高 い危険回転数を実現できる性質を利用している。 チューブ 部分の CFRP 化による軽量化に加え, 中間軸受の省略に よる 1 軸化で, 組み付け部品重量でスチール品比 $50 \%$ の 軽量化（約 $6 \mathrm{~kg}$ ）を達成している.

また，CFRP 化による 1 軸化において問題となる正面衝 突時の車体エネルギー吸収阻害を，独自の CFRP 設計に より回避し, 搭載車種の優れた安全性を引き出している. 衝突時にシャフトへ軸圧縮荷重が負荷された時にチューブ 自体が破壊する新規メカニズムが組み达まれており，その 結果，車体のエネルギー吸収性能を最適に実現することを 可能としている゙ .

上記“パジェロ”を皮切りに“フェアレディZ”（日産） や“RX-8”(マツダ) などへの採用が進み, 生産台数は累 計 84 万本に達している.

\section{2 ボンネット}

ボンネットなどの外板は，従来からサードパーティが カーボン製品を市販しているが，自動車メーカーが量産車 にCFRP 製ボンネットを標準装備したのは，2000 年の日 産“スカイライン” GT-R（V-spec II）（R 34）が世界初で ある(図 9)。この CFRP 製ボンネットの特徴は, CFRP 製のアウターとインナーを一体構造としている点にあり, 両部品でボンネットとしての機能を発現する新しい構造を 設計している。 その結果，この構造はアルミ製フードと同 等の剛性を持ち, 且つ完全に取り付け互換性を有した上で, 既存のアルミ製より $4 \mathrm{~kg}$ の軽量化を実現している.

\section{3 リアスポイラー}

CFRP 製大型リアスポイラーが三菱自動車“ランサーエ ボリューション” VIII， IXに採用されている (図 10). 航空 機分野で開発された高効率の薄型の翼断面を，中間の支え 無く車幅全幅に渡している。これは CFRP の持つ高強度 と高剛性により実現可能となったデザインである。さらに 従来のブロー成形品より約 $3 \mathrm{~kg}$ の軽量化を成し, 且つ構 造全体の剛性は格段に向上している.“ランサーエボリュー ション” 项のスポイラー翼構造はフォームコアを芯材にし た CFRP サンドイッチ構造となっているが, 次モデルの IXでは中空構造に進化し, 重心が下がり, 上部重量の一層 の軽量化を実現している. 

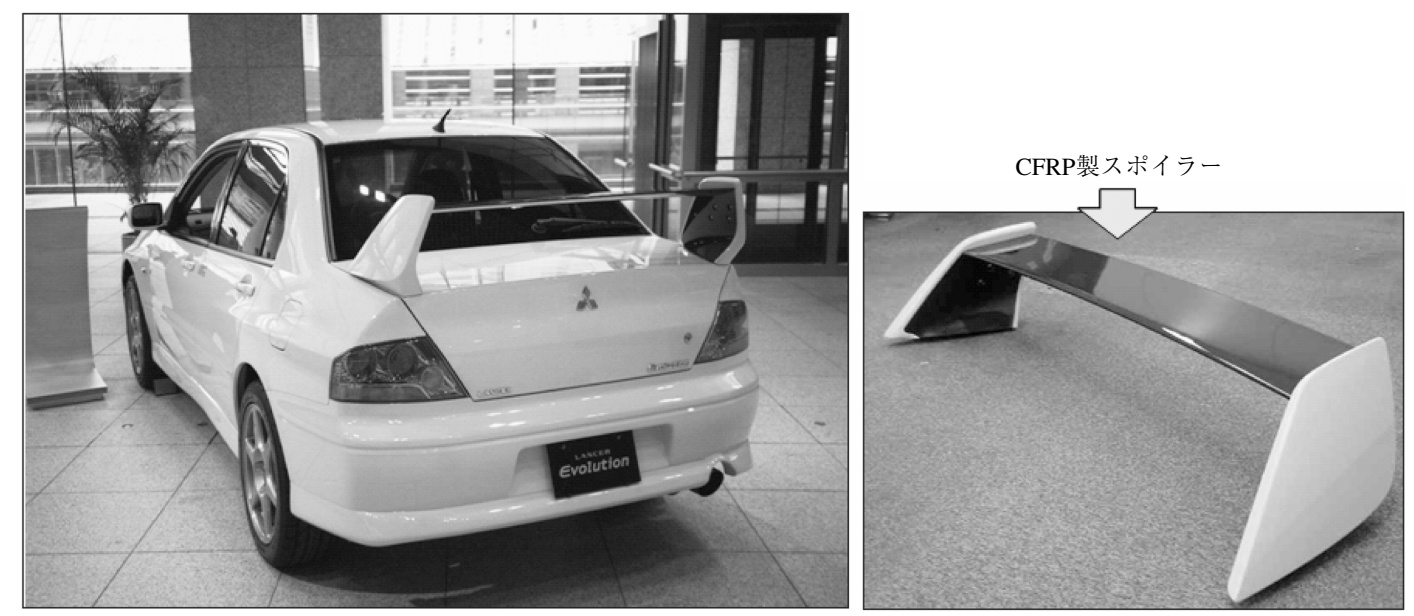

図 10 スポイラー

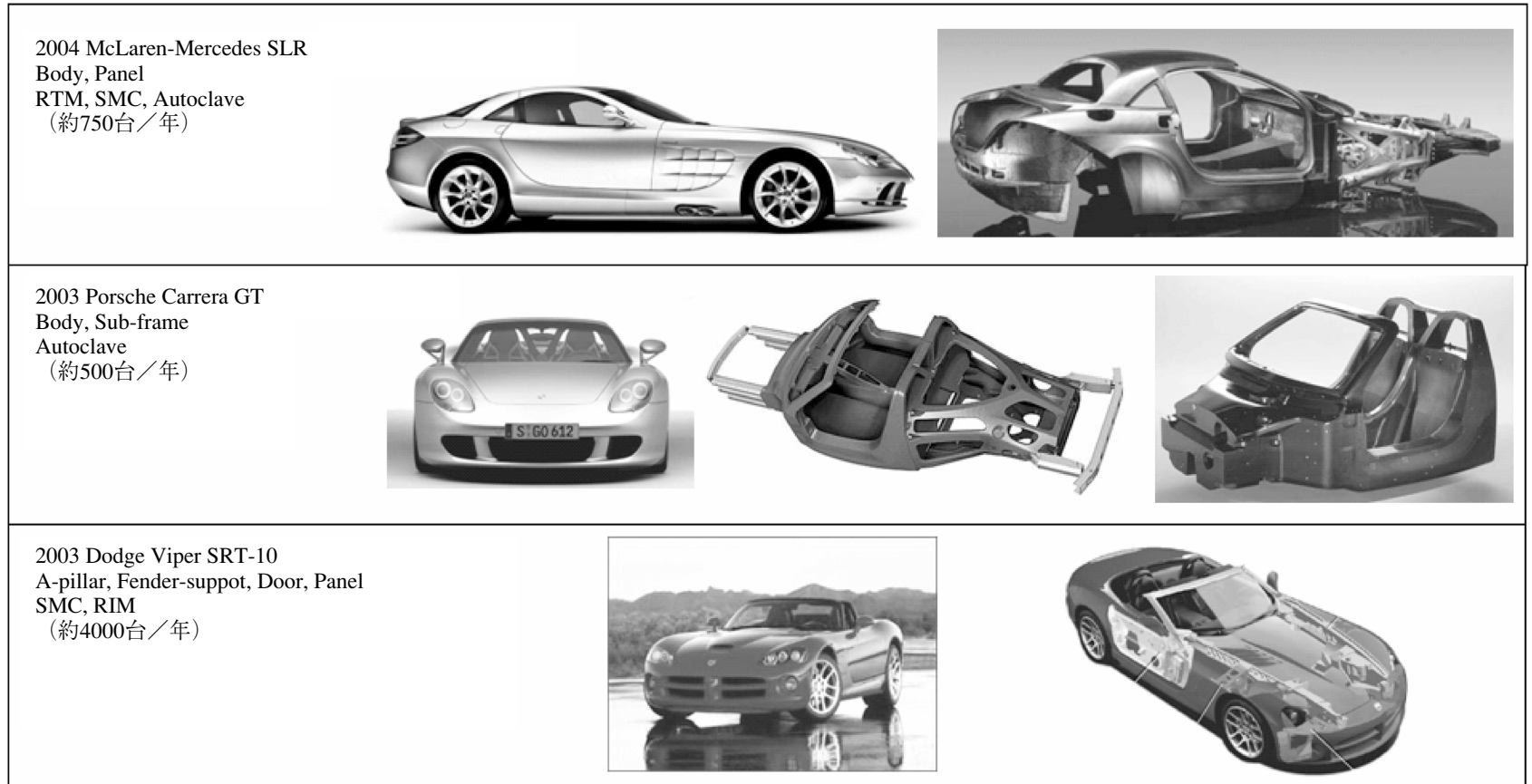

図 11 欧米車の採用事例

\section{4 欧米の事例}

図 11 に欧米車の事例をまとめる。これらは自動車の 1 次構造を CFRP 化しており，極めて先進的である. CFRP 化の進んだ F 1 レーシングカーのコンセプトが商用車へ展 開されており，今後，高級スポーツカーでは主流となる可 能性が高い。

\section{5. 最 後に}

(財)自動車研究所のアンケート調査 (2002 年) ${ }^{5}$ では, CFRP の自動車への大量採用は，2018 年頃から開始されると予 測している。また超低燃費自動車（2Ｌカー）は 2015 年 にハイブリッド方式で普及し, 燃料電池方式の普及は 2020 年以降になると言われている。これら高効率自動車の実現 に軽量化は必須である。予想年まであと 10 年程となった 現在，軽量高性能材料である CFRP が自動車分野で広く
使われるための研究開発が加速している.

\section{参 考 文 献}

1 ）新聞発表などの公開情報による.

2 ）関戸俊英：「CFRP の成形技術と車両への適用」，自動 車技術講習会資料（自動車技術会中部支部），第 56 回 (2003)

3 ) Yamasaki, M., et al., The 12th US-Japan Conference on Composite Materials, 475 (2006)

4 ) Kyono, T., Kimoto, Y. and Kawanomoto, Y.: “Carbon Fiber Composites Applications For Auto Industries", 3rd Annual SPE Automotive Composites Conference Technical Papers (2003)

5 ）堀政彦：「アンケート調査による自動車技術の将来動 向調査」, 自動車研究，24(9)，367(2002) 